\title{
Nitrogen and potassium fertilization on cabbage biometrics and foliar nutritional levels
}

Fertilização nitogenada e potássica na biometria e níveis nutricionais foliares do repolho

\author{
A. C. M. M. Silva'; H. C. de O. Charlo' ; P. F. $\operatorname{Vargas}^{2}$; J. L. R. Torres ${ }^{1}$; O. F. da \\ Silva Neto ${ }^{1} ;$ E. M. Lemes ${ }^{3 *}$ \\ ${ }^{I}$ Instituto Federal de Educação, Ciência e Tecnologia do Triângulo Mineiro (IFTM), campus Uberaba, 38064-190, \\ Uberaba-MG, Brazil. \\ ${ }^{2}$ Universidade Estadual de São Paulo (UNESP), campus Registro, 11900-000, Registro-SP, Brazil. \\ ${ }^{3}$ Universidade Federal de Uberlândia (UFU), campus Glória, 38410-337, Uberlândia-MG, Brazil. \\ *ernanefito@gmail.com
}

(Recebido em 18 de outubro de 2020; aceito em 18 de janeiro de 2021)

\begin{abstract}
Among the most absorbed nutrients by cabbage, nitrogen $(\mathrm{N})$ and potassium $(\mathrm{K})$ are the most extracted; thus, the objective of this study was to evaluate the responses of $\mathrm{N}$ and $\mathrm{K}$ fertilization on the cabbage biometrics and foliar levels of macro and micronutrients. Four $\mathrm{N}$ doses $\left(0,75,150,300 \mathrm{~kg} \mathrm{ha}^{-1}\right.$ of $\left.\mathrm{N}\right)$ and four $\mathrm{K}$ doses $\left(0,75,150,300 \mathrm{~kg} \mathrm{ha}^{-1}\right.$ of $\left.\mathrm{K}_{2} \mathrm{O}\right)$. Biometrics of cabbage head (height, circumference and diameter) and productivity were evaluated. The cabbage levels of macro and micronutrients were also evaluated in leaves of plants at the phenological stage of head-formation. Nitrogen fertilization did not significantly affect the variables evaluated mostly due to the great natural fertility of the experimental soil area. This lack of response highlights the importance of constant monitoring of the nutritional status of the productive area to avoid nonnecessary $\mathrm{N}$ fertilization. The lowest $\mathrm{Mg}$ leaf content was observed at $88 \mathrm{~kg} \mathrm{ha}^{-1}$ of $\mathrm{K}_{2} \mathrm{O}$, after which the $\mathrm{Mg}$ leaf content increased. The foliar $\mathrm{Zn}$ was reduced in doses after $133 \mathrm{~kg} \mathrm{ha}^{-1}$ of $\mathrm{K}_{2} \mathrm{O}$. The cabbage head diameter and circumference decreased with the increase of the $\mathrm{K}_{2} \mathrm{O}$ doses. The cabbage head height increased up to $128 \mathrm{~kg} \mathrm{ha}^{-1}$ of $\mathrm{K}_{2} \mathrm{O}$. The decreasing sequence of the macro and micronutrient levels in cabbage leaves followed the sequence $\mathrm{K}>\mathrm{Ca}>\mathrm{N}>\mathrm{S}>\mathrm{Mg}>\mathrm{P}$ and $\mathrm{Mn}>\mathrm{Fe}>\mathrm{B}>\mathrm{Zn}>\mathrm{Cu}$ regardless of the level of the factors applied.
\end{abstract}

Keywords: Brassica oleracea var. capitata, crop yield, plant mineral nutrition

Entre os nutrientes mais absorvidos pela cultura do repolho, o nitrogênio $(\mathrm{N})$ e o potássio $(\mathrm{K})$ são os mais extraídos. Assim, o objetivo deste estudo foi avaliar as respostas da fertilização de $\mathrm{N}$ e $\mathrm{K}$ sobre a biometria de repolho e os níveis foliares de macro e micronutrientes. Quatro doses de $\mathrm{N}\left(0,75,150,300 \mathrm{~kg} \mathrm{ha}^{-1} \mathrm{de} \mathrm{N}\right)$ e quatro doses de $\mathrm{K}\left(0,75,150,300 \mathrm{~kg} \mathrm{ha}^{-1}\right.$ de $\left.\mathrm{K}_{2} \mathrm{O}\right)$. Foram avaliadas a biometria da cabeça de repolho (altura, circunferência e diâmetro) e produtividade. Os níveis de macro e micronutrientes nas folhas de repolho também foram avaliados na fase fenológica da formação da cabeça. A fertilização nitrogenada não afetou significativamente as variáveis avaliadas principalmente devido à grande fertilidade natural da área experimental do solo. A falta de resposta destaca a importância do monitoramento constante do estado nutricional da área produtiva para evitar fertilizações nitrogenadas desnecessárias. O menor teor foliar de $\mathrm{Mg}$ foi com a aplicação de $88 \mathrm{~kg} \mathrm{ha}^{-1} \mathrm{de} \mathrm{K}_{2} \mathrm{O}$, após esta dose o teor foliar de $\mathrm{Mg}$ aumentou. $\mathrm{O} \mathrm{Zn}$ foliar foi reduzido em doses superiores s $133 \mathrm{~kg} \mathrm{ha}^{-1}$ de $\mathrm{K}_{2} \mathrm{O}$. O diâmetro da cabeça de repolho e a circunferência diminuíram com o aumento das doses de $\mathrm{K}_{2} \mathrm{O}$. A altura da cabeça do repolho aumentou com a aplicação de até $128 \mathrm{~kg} \mathrm{ha}^{-1}$ de $\mathrm{K}_{2} \mathrm{O}$. A sequência decrescente dos níveis de macro e micronutrientes nas folhas de repolho seguiu a sequência $\mathrm{K}>\mathrm{Ca}>\mathrm{N}>\mathrm{S}>\mathrm{Mg}>\mathrm{P}$ e $\mathrm{Mn}>\mathrm{Fe}>\mathrm{B}>\mathrm{Zn}>\mathrm{Cu}$ independentemente do nível dos fatores aplicados.

Palavras-chave: Brassica oleracea var. capitata, produção agrícola, nutrição mineral de plantas

\section{INTRODUCTION}

Cabbage (Brassica oleracea var. capitata) is the one of the most cultivated crops of the Brassicaceae plant family and genetic breeding improvements has generated cabbage cultivars able to be cultivated during the whole year [1]. This horticultural crop is of a short cycle, shallow root system, and, therefore, needs high quantities of nutrients to express its productive potential and 
quality [2]. The cabbage crop extracts and exports high quantities of nutrients. The nitrogen $(\mathrm{N})$ and potassium $(\mathrm{K})$ are the most extracted nutrients $[3 ; 4]$.

According to Wang et al. (2013) [4], $\mathrm{K}$ is essential to the formation and translocation of carbohydrates, it improves the efficiency of water uses and increases the commercial quality of the final product (cabbage head). Domingues Neto et al. (2016) [5] reported that to obtain high yields the cabbage cannot undergo nutritional deficiencies, being the $\mathrm{N}$ essential to the production of compact cabbage head (great firmness) desired by the market.

Despite the importance of cabbage nutritional management and cabbage economic and social impact, there are few studies on the appropriate management of the crop fertilization. Duarte et al. (2019) [6] report that there is a disagreement between the applications of fertilizers as recommended in literature and the effectively applied fertilizers by farmers, who generally use higher doses of nutrients. According to Zhang et al. (2010) [7], the current management of $\mathrm{N}$ does not provide nutrients in balance with the crop needs, thus resulting in wasted fertilizers and low efficiency of nutrient recovery.

Therefore, the best relation of nutrients applied contributes to high productivity, reduced production costs, and low environmental impacts. Given this, the objective of this study was to evaluate the effect of doses of $\mathrm{N}$ and $\mathrm{K}$ in the biometrics and foliar levels of macro and micronutrients.

\section{MATERIAL AND METHODS}

This study was conducted in an experimental area of the horticulture sector of the Federal Institute of Education, Science and Technology of the Triângulo Mineiro (IFTM), campus Uberaba, Brazil. The area is located at the coordinates $19^{\circ} 39^{\prime} 19^{\prime \prime} \mathrm{S}$ and $47^{\circ} 57^{\prime} 27^{\prime \prime} \mathrm{W}, 800 \mathrm{~m}$ above sea level. The climate, based on the international classification of Köppen, is Aw (tropical, hot and humid summer, with cold, dry winter) [8]. During the experiment, the accumulated precipitation and temperature averaged $672.68 \mathrm{~mm}$ and $23.8^{\circ} \mathrm{C}$, respectively.

The soil of the experimental area is a Dystrophic Red Latosol with medium texture ( $21 \%$ clay) [9]. The experimental area was destined for vegetable production for many years using organic and mineral fertilization. Previously to the cultivation of cabbage for the present study, the area was cultivated with green corn. Soil samples were collected before experiment installation at $0-0.2 \mathrm{~m}$ soil layer, and the soil chemical characteristics were analyzed according to the methodology described by Raij et al. (2001) [10]. The soil chemical results are presented in Table 1.

Table 1. Soil chemical characterization at 0-0.2 $\mathrm{m}$ soil layer.

\begin{tabular}{|c|c|c|c|c|c|c|c|c|c|c|}
\hline \multirow{2}{*}{$\begin{array}{c}\mathrm{pH} \\
\mathrm{CaCl}\end{array}$} & $\mathrm{Ca}$ & $\mathrm{Mg}$ & $\mathrm{Al}$ & $\mathrm{H}+\mathrm{Al}$ & BS & CEC & \multirow{2}{*}{$\begin{array}{c}\mathrm{V} \\
(\%)\end{array}$} & $\mathrm{K}$ & $\mathrm{P}$ & \multirow{2}{*}{$S$} \\
\hline & --- & ------- & $--(\mathrm{cmc}$ & $\left.\mathrm{dm}^{-3}\right)-$ & & ---- & & \multicolumn{2}{|c|}{--------(mg dm $\left.{ }^{-3}\right)-----$} & \\
\hline 4.66 & 0.90 & 0.22 & 0.39 & 3.37 & 1.48 & 4.84 & 30 & 138 & 48 & 10 \\
\hline S.O.M & \multicolumn{2}{|c|}{ B } & \multicolumn{2}{|c|}{$\mathrm{Cu}$} & \multirow{2}{*}{\multicolumn{2}{|c|}{$\mathrm{Fe}$}} & \multirow{2}{*}{\multicolumn{2}{|c|}{$\mathrm{Mn}$}} & \multicolumn{2}{|c|}{$\mathrm{Zn}$} \\
\hline $\mathrm{g} . \mathrm{kg}^{-1}$ & \multicolumn{4}{|c|}{----- } & & & & & & \\
\hline 36.33 & & & & & & & \multicolumn{2}{|c|}{28} & \multicolumn{2}{|c|}{3.29} \\
\hline
\end{tabular}

$\mathrm{Ca}, \mathrm{Mg}, \mathrm{Al}=\mathrm{KCl}$ solution $\left(1 \mathrm{~mol} \mathrm{~L}^{-1}\right) ; \mathrm{H}+\mathrm{Al}=\mathrm{SMP}$ buffer solution $(\mathrm{pH} 7.5) ; \mathrm{BS}=$ base sum $\left(\mathrm{cmol}_{\mathrm{c}} \mathrm{dm}^{-}\right.$ ${ }^{3}$ ); $\mathrm{CEC}=$ cation exchange capacity at $\mathrm{pH} 7 \mathrm{~V}=$ saturation of bases; $\mathrm{K}=0.05 \mathrm{~mol} \mathrm{~L}^{-1} \mathrm{HCl}+\mathrm{H}_{2} \mathrm{SO}_{4} 0.0125$ mol L ${ }^{-1} ; \mathrm{P}=$ resin; $\mathrm{S}=$ calcium phosphate; $\mathrm{S} . \mathrm{O} . \mathrm{M} .=$ soil organic matter (colorimetric method). $\mathrm{B}, \mathrm{Cu}, \mathrm{Fe}$, $\mathrm{Mn}, \mathrm{Zn}=$ DTPA acid. Methodologies source: [10].

According to the soil chemical analysis, lime was applied to raise the soil base saturation to $70 \%$ as recommended by the Committee of Soil Fertility of the Minas Gerais State (Comissão de Fertilidade do Solo do Estado de Minas Gerais) [11] for cabbage. The lime was calcined limestone $($ RPTN $=120)$, distributed in a single dose $\left(1,600 \mathrm{~kg} \mathrm{ha}^{-1}\right)$, and subsequently incorporated into the soil with plowing and harrowing to the $0-0.2 \mathrm{~m}$ soil depth. 
The experimental design used was randomized blocks with four replications in a $4 \times 4$ factorial scheme, being four doses of $\mathrm{N}\left(0,75,150\right.$ and $\left.300 \mathrm{~kg} \mathrm{ha}^{-1} \mathrm{~N}\right)$ and four doses of $\mathrm{K}(0,75,150$ and $300 \mathrm{~kg} \mathrm{ha}^{-1}$ of $\left.\mathrm{K}_{2} \mathrm{O}\right)$. The sources of $\mathrm{N}$ and $\mathrm{K}$ were urea $(45 \% \mathrm{~N})$ and potassium chloride $(56 \%$ of $\mathrm{K}_{2} \mathrm{O}$ ), respectively.

The basic soil fertilization occurred two days before seedling transplant, and $300 \mathrm{~kg} \mathrm{ha}^{-1}$ of $\mathrm{P}_{2} \mathrm{O}_{5}$ and $20 \%$ of the $\mathrm{N}$ and $\mathrm{K}$ doses were applied. The remaining $\mathrm{N}$ and $\mathrm{K}$ doses for each treatment was applied in three moments: $20 \%$ of the dose applied to the 15 days after seedling transplant, $30 \%$ applied 15 days after the first application, and 30\% applied 15 days after the second application. During the experiment, three fertilizations with boron (B, $1 \mathrm{~g} \mathrm{~L}^{-1}$ of boric acid) and molybdenum (Mo, $0.5 \mathrm{~g} \mathrm{~L}^{-1}$ of ammonium molybdate) occurred via foliar applications. The $\mathrm{B}$ and Mo fertilizations were 20 days after emergence and 15 and 30 days after the seedling transplant.

Each experimental plot had $3.5 \mathrm{~m}$ length and two planting lines with seven plants each (14 plants per plot). The spacing between planting rows and between plants were 0.8 and $0.5 \mathrm{~m}$, respectively. The cultivar studied was the Fênix (Sakata®), a cultivar with medium head size, semi-flat format, moderate resistance to Xanthomonas campestris pv. campestres, average weight of $3 \mathrm{~kg}, 110$ days cycle, and high resistance to cracking. The sowing was performed in March 2016, in polystyrene trays with 128 cells, filled with commercial substrate recommended for the production of vegetable seedlings. The trays were placed in a protected environment, and at 35 days after sowing the seedling transplantation to the experimental area.

The phytosanitary control was performed whenever necessary after daily inspection to verify the need for weed, insect pests, and disease control. Plant weeds were removed manually. The irrigation occurred through a spray system and performed whenever it was necessary for the maintenance of the soil field capacity.

At the beginning of the head formation, newly mature cabbage leaves were collected from each plot to determine plant nutritional status based on the cabbage nutritional status proposed by Trani and Raij (1997) [12]. The leaves were gently washed and dried for the determination of foliar nutrient levels (N, P, K, Ca, S, Mg, B, Cu, Fe, Mn, Zn). The preparation and foliar analyses were performed according to the methodology proposed by Carmo et al. (2000) [13].

The harvest was started in July 2016, at 83 days after the transplant, when the cabbage heads were compact and fully developed, presenting excellent market characteristics. In each plot, the central eight plants were harvested and weighed to obtain the fresh mass of the cabbage head with adjacent leaves (CML) and fresh mass of the commercial cabbage head (without adjacent leaves) $(\mathrm{CCH})$. The height, circumference and diameter of the cabbage head were measured with the aid of a ruler and a metric tape.

The data of the evaluated variables were submitted to ANOVA and regression analysis $(\mathrm{p}<0.05)$, using the package ExpDes of the $\mathrm{R}$ statistical program. The model that better fits the data and significantly described the relationship between the two variables was selected and presented in graphs.

\section{RESULTS AND DISCUSSION}

There was no interaction between the factors ( $\mathrm{N}$ and $\mathrm{K}$ fertilization) for any of the variables evaluated in the present study. The assessment of the nutritional status of the cabbage leaves indicated that the factors did not affect the levels of nutrients. Except for the $\mathrm{Mg}$ and $\mathrm{Zn}$ and only with the $\mathrm{K}$ fertilization (Table 2).

The $\mathrm{Mg}$ and $\mathrm{Zn}$ responses adequate to the quadratic polynomial model of response to doses of $\mathrm{K}_{2} \mathrm{O}$ (Figure 1). The lowest content of $\mathrm{Mg}$ observed in the cabbage leaves was with a dose of $88 \mathrm{~kg}$ $\mathrm{ha}^{-1}$ of $\mathrm{K}_{2} \mathrm{O}$, from which the $\mathrm{Mg}$ leaf content increases. The $\mathrm{K}$ application is recognized by competitively inhibiting the absorption of $\mathrm{Mg}$ [14]. This was not observed for the present study, where only an initial decrease in the $\mathrm{Mg}$ level was observed. However, the level foliar $\mathrm{Zn}$ reduces after a certain dose of $\mathrm{K}_{2} \mathrm{O} ; \mathrm{Zn}$ is absorbed by plants as $\mathrm{Zn}^{2+}$, and in the case of this cationic micronutrient, doses above $132,8 \mathrm{~kg} \mathrm{ha}^{-1}$ sharply reduces $\mathrm{Zn}$ foliar levels in cabbage. 
Table 2. Cabbage foliar averages and analysis of variance of the nutrients evaluated as a function of nitrogen and potassium fertilization.

\begin{tabular}{|c|c|c|c|c|c|c|c|c|c|c|c|}
\hline \multirow{2}{*}{$\begin{array}{c}\mathrm{N} \\
\left(\mathrm{kg} \mathrm{ha}^{-1}\right)\end{array}$} & $\mathrm{N}$ & $\mathrm{P}$ & $\mathrm{K}$ & $\mathrm{Ca}$ & $\mathrm{Mg}$ & S & B & $\mathrm{Cu}$ & $\mathrm{Fe}$ & $\mathrm{Mn}$ & $\mathrm{Zn}$ \\
\hline & \multicolumn{11}{|c|}{---------------------(g kg-1)------------------- } \\
\hline 0 & 16.11 & 2.66 & 33.28 & 20.46 & 3.15 & 7.69 & 5.25 & 4.06 & 106.31 & 191.81 & 45.94 \\
\hline 75 & 17.06 & 2.66 & 34.28 & 20.45 & 3.29 & 7.85 & 6.69 & 4.19 & 103.81 & 166.38 & 43.44 \\
\hline 150 & 13.66 & 2.63 & 35.16 & 21.49 & 3.37 & 11.69 & 6.31 & 4.00 & 91.50 & 244.69 & 42.50 \\
\hline 300 & 16.13 & 2.63 & 34.69 & 22.28 & 3.49 & 10.39 & 6.69 & 3.94 & 107.63 & 186.00 & 43.75 \\
\hline \multicolumn{12}{|l|}{$\begin{array}{c}\mathrm{K}_{2} \mathrm{O} \\
\left(\mathrm{kg} \mathrm{ha}^{-1}\right)\end{array}$} \\
\hline 0 & 17.98 & 2.59 & 33.97 & 21.34 & 3.24 & 8.89 & 4.56 & 3.94 & 108.75 & 196.19 & 39.81 \\
\hline 75 & 16.51 & 2.68 & 34.84 & 20.64 & 3.24 & 7.46 & 6.56 & 4.13 & 97.00 & 177.25 & 51.81 \\
\hline 150 & 16.04 & 2.77 & 33.84 & 21.11 & 3.05 & 11.70 & 6.50 & 4.06 & 101.88 & 193.75 & 47.25 \\
\hline 300 & 12.44 & 2.53 & 34.75 & 21.59 & 3.76 & 9.56 & 7.31 & 4.06 & 101.63 & 221.69 & 36.75 \\
\hline $\mathrm{F}_{\mathrm{N}}$ & $0.91^{\mathrm{ns}}$ & $0.09^{\mathrm{ns}}$ & $1.84^{\mathrm{ns}}$ & $1.38^{\mathrm{ns}}$ & $1.57^{\mathrm{ns}}$ & $0.66^{\mathrm{ns}}$ & $0.84^{\mathrm{ns}}$ & $0.64^{\mathrm{ns}}$ & $0.77^{\mathrm{ns}}$ & $0.88^{\mathrm{ns}}$ & $0.23^{n}$ \\
\hline $\mathrm{F}_{\mathrm{K}}$ & $2.39^{\mathrm{ns}}$ & $2.64^{\mathrm{ns}}$ & $0.77^{\mathrm{ns}}$ & $0.29^{\mathrm{ns}}$ & $7.15^{* *}$ & $0.54^{\mathrm{ns}}$ & $2.49^{\mathrm{ns}}$ & $0.35^{\mathrm{ns}}$ & $0.33^{\mathrm{ns}}$ & $0.26^{\mathrm{ns}}$ & $5.05^{*}$ \\
\hline $\mathrm{F}_{\mathrm{NxK}}$ & $1.09^{\mathrm{ns}}$ & $0.46^{\mathrm{ns}}$ & $0.94^{\mathrm{ns}}$ & $2.04^{\mathrm{ns}}$ & $1.51^{\mathrm{ns}}$ & $0.94^{\mathrm{ns}}$ & $1.16^{\mathrm{ns}}$ & $0.49^{\mathrm{ns}}$ & $0.34^{\mathrm{ns}}$ & $0.58^{\mathrm{ns}}$ & $0.66^{\mathrm{n}}$ \\
\hline C.V. $(\%)$ & 38.68 & 9.87 & 6.85 & 14.19 & 13.62 & 102.16 & 47.71 & 13.19 & 32.88 & 72.34 & 27.85 \\
\hline \multicolumn{12}{|c|}{$\begin{array}{l}\mathrm{N}=\text { nitrogen dose; } \mathrm{K}_{2} \mathrm{O}=\text { potassium oxide dose; } \mathrm{ns}=\text { non-significant; “**” = significant at } 1 \% \text { probability } \\
\text { the } F \text { test; } \mathrm{F}_{\mathrm{N}}: F \text { test value for the factor } \mathrm{N} \text { doses; } \mathrm{F}_{\mathrm{K}}: F \text { test value for the factor } \mathrm{K} \text { doses; } \mathrm{F}_{\mathrm{NxK}}: F \text { test value } \\
\text { the interaction between the } \mathrm{N} \text { and } \mathrm{K} \text { factors; } \mathrm{C} . \mathrm{V} .(\%)=\text { coefficient of variation. }\end{array}$} \\
\hline 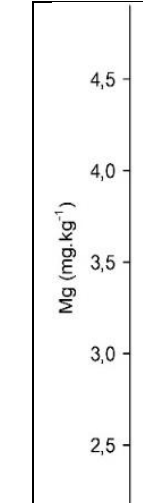 & $\begin{array}{l}M g=3.2 \\
R^{2}=90 .\end{array}$ & $0.0035^{5} x+0$ & $002^{2} x^{2}$ & & & 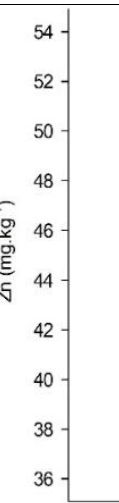 & $\begin{array}{l}I \\
Z^{2}=41.13+ \\
R^{2}=85.02 \%\end{array}$ & $1328^{8} x-0.000$ & $\bullet$ & 1 & \\
\hline & 0 & 75 & $\left(\mathrm{~kg} . \mathrm{h}^{-1}\right)^{15}$ & & 00 & & 0 & 5 & $\left.h a^{-1}\right)$ & & \\
\hline
\end{tabular}

Figure 1. Cabbage foliar levels of magnesium (left graph) and zinc (right graph) as a function of potassium fertilizer. Each point in both graphs is an average of 16 observations. Bars represent standard error.

The decreasing sequence of the macronutrient levels in cabbage leaves followed the sequence $\mathrm{K}>\mathrm{Ca}>\mathrm{N}>\mathrm{S}>\mathrm{Mg}>\mathrm{P}$, regardless of the level of the factors ( $\mathrm{N}$ and $\mathrm{K}$ fertilization) applied. Among the micronutrients, the sequence was $\mathrm{Mn}>\mathrm{Fe}>\mathrm{B}>\mathrm{Zn}>\mathrm{Cu}$. The macronutrient levels observed at this cabbage phonological stage differed from [15], who reported superior foliar K levels compared to the $\mathrm{N}$ levels. However, current cabbage hybrids have shown Ca leaf concentration greater than those of $\mathrm{N}$, as reported by [3], corroborating the results found in the present study.

Berça, Mendonça and Souza (2019) [16] evaluated the levels of macro and micronutrients in cabbage leaves at harvest. They also observed that the macronutrient content followed the sequence $\mathrm{N}>\mathrm{K}>\mathrm{Ca}>\mathrm{S}>\mathrm{Mg}>\mathrm{P}$, and micronutrients followed the sequence $\mathrm{Fe}>\mathrm{Mn}>\mathrm{Cu}>\mathrm{Zn}>\mathrm{B}$. Differences in the crop management (e.g., nutrition, irrigation, genotype), as well as soil differences, can affect the results of the experiments; however, the differences between the results observed by Berça, Mendonça and Souza (2019) [16] and the results of the present study are probably due to the time 
of evaluation of the cabbage leaves. In both experiments, the macronutrients $\mathrm{N}, \mathrm{Ca}$ and $\mathrm{K}$, and the micronutrients Fe and Mn were the most accumulated by cabbage leaves.

The cabbage biometric evaluations (height, diameter, weight and masses) indicated that the $\mathrm{N}$ fertilization did not affect these variables for the edaphic conditions of this study. Very likely, the $\mathrm{N}$ for the full crop development was supplied by the soil organic matter [17], which in this study was $36.33 \mathrm{~g} \mathrm{dm}^{-3}$, masking the effect of the $\mathrm{N}$ fertilization. However, these variables were affected by the factor: $\mathrm{K}$ fertilization $(\mathrm{p}<0.05)($ Table 3$)$.

Table 3. Cabbage biometric averages and analysis of variance of the nutrients evaluated as a function of nitrogen and potassium fertilization.

\begin{tabular}{cccccc}
\hline $\begin{array}{c}\mathrm{N} \\
\left(\mathrm{kg} \mathrm{ha}^{-1}\right)\end{array}$ & $\begin{array}{c}\text { Head height } \\
(\mathrm{cm})\end{array}$ & $\begin{array}{c}\text { Diameter } \\
(\mathrm{cm})\end{array}$ & $\begin{array}{c}\text { Circumference } \\
(\mathrm{cm})\end{array}$ & $\begin{array}{c}\text { CML } \\
\left(\mathrm{kg} \mathrm{planta}^{-1}\right)\end{array}$ & $\begin{array}{c}\mathrm{CCH} \\
\left(\mathrm{kg} \mathrm{planta}^{-1}\right)\end{array}$ \\
\hline 0 & 10.87 & 13.97 & 47.40 & 1.16 & 0.96 \\
75 & 11.02 & 14.10 & 46.88 & 1.04 & 0.94 \\
150 & 11.52 & 14.48 & 47.81 & 1.25 & 1.09 \\
300 & 11.32 & 14.77 & 49.04 & 1.42 & 1.23 \\
\hline $\mathrm{K}_{2} \mathrm{O}$ & & & & & \\
\hline $\left.\mathrm{kg} \mathrm{ha}^{-1}\right)$ & & 14.65 & 49.20 & 1.13 & 1.01 \\
\hline 0 & 11.00 & 14.64 & 48.39 & 1.47 & 1.25 \\
75 & 11.55 & 14.50 & 47.76 & 1.34 & 1.17 \\
150 & 11.50 & 13.54 & 45.79 & 0.94 & 0.79 \\
300 & 10.68 & $1.70^{\mathrm{ns}}$ & $2.46^{\mathrm{ns}}$ & $2.26^{\mathrm{ns}}$ & $2.17^{\mathrm{ns}}$ \\
\hline $\mathrm{F}_{\mathrm{N}}$ & $2.42^{\mathrm{ns}}$ & $3.63^{*}$ & $6.17^{* *}$ & $5.00^{* *}$ & $4.86^{* *}$ \\
$\mathrm{~F}_{\mathrm{K}}$ & $4.90^{* *}$ & $0.62^{\mathrm{ns}}$ & $1.53^{\mathrm{ns}}$ & $1.78^{\mathrm{ns}}$ & $1.92^{\mathrm{ns}}$ \\
$\mathrm{F}_{\mathrm{NxK}}$ & $0.69^{\mathrm{ns}}$ & 7.84 & 4.91 & 34.72 & 34.87 \\
\hline C.V. $(\%)$ & 6.76 & & & & \\
\hline
\end{tabular}

$\mathrm{N}=$ nitrogen dose $; \mathrm{K}_{2} \mathrm{O}=$ potassium oxide dose; $\mathrm{ns}=$ non-significant; “*” and "*** = significant at 5 and $1 \%$ probability by the $F$ test, respectively; $\mathrm{F}_{\mathrm{N}}: F$ test value for the factor $\mathrm{N}$ doses; $\mathrm{F}_{\mathrm{K}}: F$ test value for the factor $\mathrm{K}$ doses; $\mathrm{F}_{\mathrm{NxK}}: F$ test value for the interaction between the $\mathrm{N}$ and $\mathrm{K}$ factors; C.V. $(\%)=$ coefficient of variation. $\mathrm{CML}=$ cabbage head fresh mass with all leaves; $\mathrm{CCH}=$ cabbage head fresh mass without all leaves (commercial cabbage head).

The height of the cabbage head was influenced by the $\mathrm{K}$ doses according to a quadratic model response (Figure 2). The maximum height of the cabbage head $(11.56 \mathrm{~cm})$ was observed with a dose of $128 \mathrm{~kg} \mathrm{ha}^{-1}$ of $\mathrm{K}_{2} \mathrm{O}$. The diameter and the circumference of the cabbage head were influenced by the doses of $\mathrm{K}_{2} \mathrm{O}$ following. Linear models of response. The initial diameter $(0 \mathrm{~kg}$ ha $^{-1}$ of K) was $14.84 \mathrm{~cm}$ and decreased approximately $0.0039 \mathrm{~cm}$ for each kilogram of $\mathrm{K}_{2} \mathrm{O}$ applied per hectare. The initial cabbage head circumference was $49.26 \mathrm{~cm}$ and decreased approximately $0.0113 \mathrm{~cm}$ for each kilogram of $\mathrm{K}_{2} \mathrm{O}$ applied per hectare.

There is a maximum dose of $\mathrm{K}_{2} \mathrm{O}\left(128 \mathrm{~kg} \mathrm{ha}^{-1}\right)$ to the cabbage head height $(11.56 \mathrm{~cm})$; however, there is a trend of negative response to the increasing doses of $\mathrm{K}_{2} \mathrm{O}$ for the other variables evaluated. This negative effect may be directly related to the saline effect of the $\mathrm{K}$ source used $(\mathrm{KCl})$ [18], or even by the competition among the cationic nutrients. 

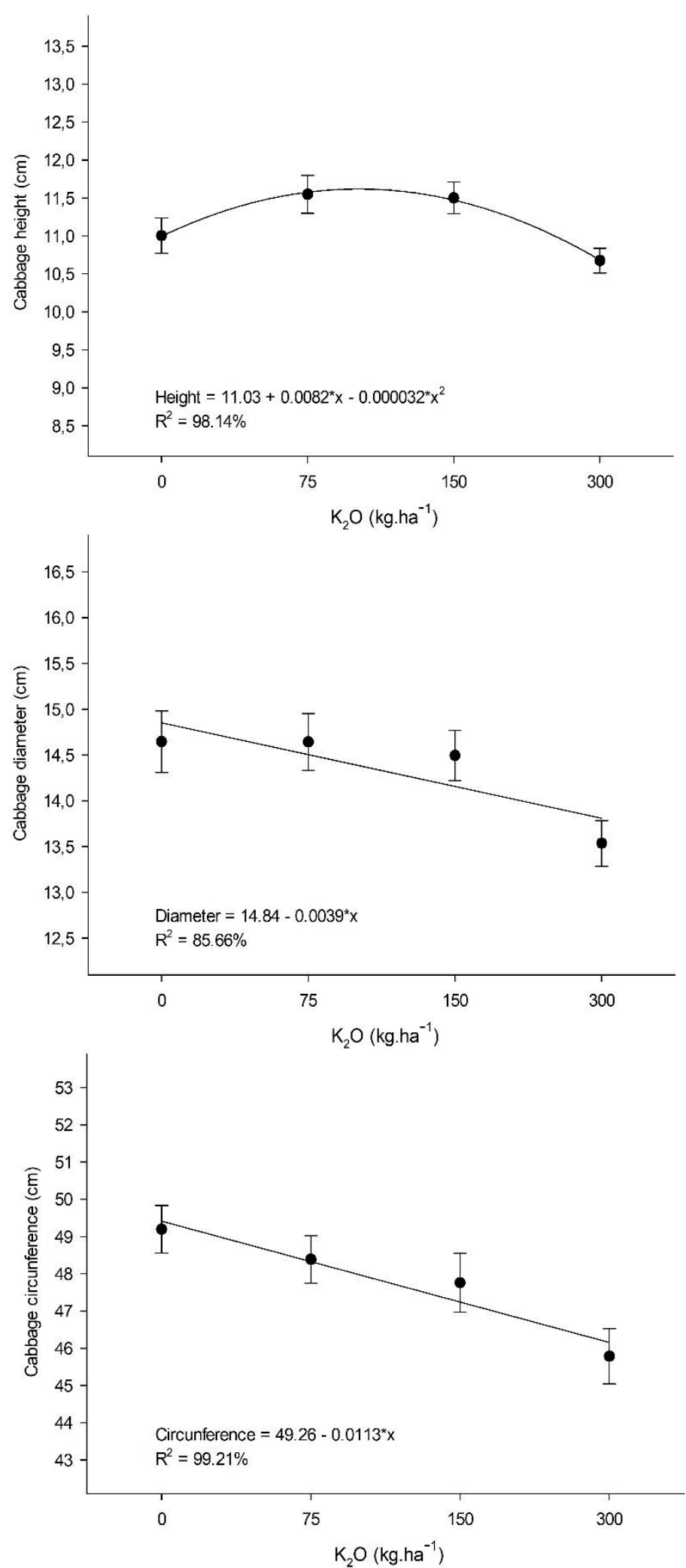

Figure 2. Cabbage height, diameter and circumference as a function of potassium fertilizer. Each dot is an average of 16 observations. Bars represent standard error.

The biomass production of cabbage heads with adjacent leaves or commercial (without adjacent leaves) were affected by the doses of $\mathrm{K}$ according to a quadratic model of response (Figure 3 ). The largest mass of cabbage head with adjacent sheets $(1.42 \mathrm{~kg})$ and the largest commercial head $(1.23$ $\mathrm{kg}$ ) were obtained with a dose of 128 and $123 \mathrm{~kg} \mathrm{ha}^{-1}$ of $\mathrm{K}_{2} \mathrm{O}$. 


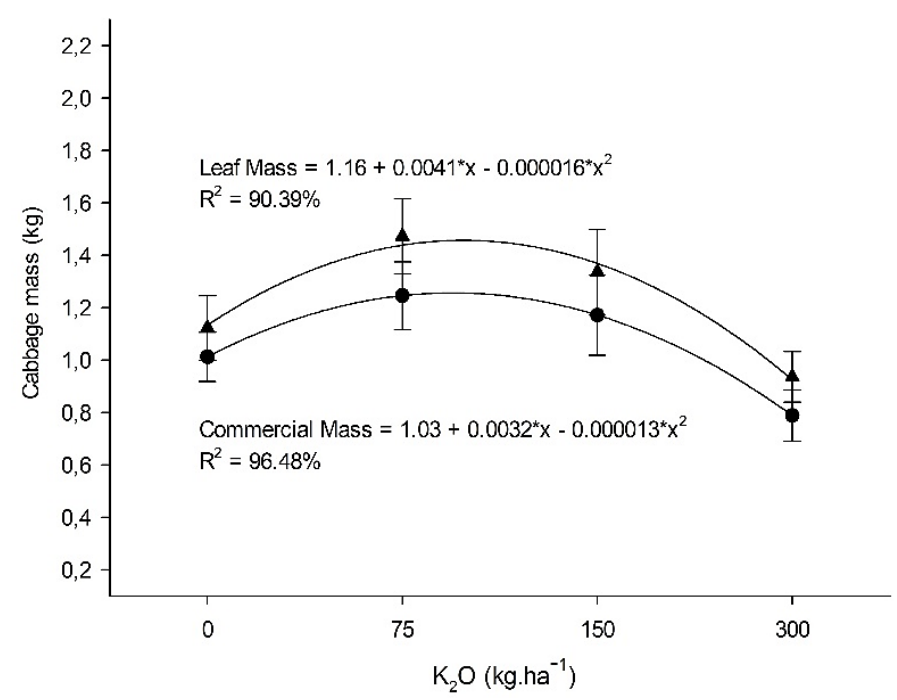

Figure 3. Mass of cabbage head with adjacent leaves and commercial (head without adjacent leaves) as a function of potassium fertilizer.

The response of cabbage to $\mathrm{N}$ is variable and depends on factors like the growing season [19] and the genotype cultivated [5]. Moreira and Vidigal (2011) [20] observed an increase of the cabbage mass with the elevation of the $\mathrm{N}$ doses of nitrogen fertilizer; however, these authors utilized $\mathrm{N}$ doses exceeding $300 \mathrm{~kg} \mathrm{ha}^{-1}$, differing from the present study. These authors also observed that the greatest mass of commercial head was $1.13 \mathrm{~kg}$ at a dose of $277.8 \mathrm{~kg} \mathrm{ha}^{-1}$ of N, which is close to the maximum value obtained in the present study, where the dose of $150 \mathrm{~kg} \mathrm{ha}^{-1}$ of $\mathrm{N}$ produced a mass of commercial head of $1.09 \mathrm{~kg}$ (Table 3).

The $\mathrm{N}$ doses applied did not affect the variables evaluated in the present study. However, Aquino et al. (2005) [1] observed that the higher average weight of cabbage heads was at the highest dose of $\mathrm{N}$ evaluated $\left(300 \mathrm{~kg} \mathrm{ha}^{-1}\right)$ and planting spacing of $0.8 \times 0.3 \mathrm{~m}$. The high soil fertilization can justify this situation in the area, a condition regularly found in areas of cultivation of vegetables. Fontanétti et al. (2006) [21] pointed out that the cultivation of cabbage may be benefited if preceded by the cultivation of sunn hemp supplemented with 20 ton ha $^{-1}$ of wet organic compost, indicating that the $\mathrm{N}$ of organic origin is important for this crop.

Cabbage showed to be responsive to $\mathrm{K}$ and with high efficiency of $\mathrm{K}$ recovery from the soil due to the high leaf content. The results indicate that increasing $\mathrm{K}$ doses significantly increase the commercial cabbage yield up to $123 \mathrm{~kg} \mathrm{ha}^{-1}$ of $\mathrm{K}_{2} \mathrm{O}$ dose. However, the study conducted by Ribas et al. (2015) [22] in a condition of considerable $\mathrm{K}$ availability in the soil $\left(\mathrm{K}=129 \mathrm{mg} \cdot \mathrm{dm}^{-3}\right)$, similar to that found in the present study ( $\mathrm{K}=138 \mathrm{mg} \cdot \mathrm{dm}^{-3}$, Table 1$)$, did not identify differences ( $\left.\mathrm{p}>0.05\right)$ in cabbage head diameter or yield, even applying $360 \mathrm{~kg} \mathrm{ha}^{-1}$ of $\mathrm{K}_{2} \mathrm{O}$. The conflicting results found by Ribas et al. (2015) [22] and in the present study demonstrates how important is to monitor and manage the soil nutrients, especially $\mathrm{K}$ for cabbage cultivation.

The excessive fertilization with $\mathrm{K}$, beyond the limit of positive, productive responses, can increase the soil salinity (especially with $\mathrm{KCl}$ as the source of $\mathrm{K}$ ) and reduce the absorption of other cations (mainly calcium and magnesium), consequently causing nutrient losses by leaching and reductions in crop yield.

The lack of significant differences among the results from $\mathrm{N}$ doses observed in this study indicates that an area managed during many seasons with vegetables can supply the cabbage $\mathrm{N}$ needs. In the case of the $\mathrm{K}$, the applied doses were able to influence the responses of the studied variables $(\mathrm{p}<0.05)$, indicating the importance of careful monitoring of the levels of $\mathrm{K}$ in the soil and the amount of $\mathrm{K}$ fertilizer applied. This monitoring between harvests prevents the occurrence of deficiencies of this nutrient in future seasons, especially after cabbage crops (high $\mathrm{K}$ consumption). 


\section{CONCLUSIONS}

Nitrogen fertilization does not significantly affect any of the variables evaluated for cabbage, indicating that for conditions similar to this study the application of $\mathrm{N}$ might not present significant increments for cabbage production.

The foliar $\mathrm{Mg}$ content decrease until the dose of $88 \mathrm{~kg} \mathrm{ha}^{-1}$ of $\mathrm{K}_{2} \mathrm{O}$, from which the foliar $\mathrm{Mg}$ content increases, and the level of foliar $\mathrm{Zn}$ reduces after $133 \mathrm{~kg} \mathrm{ha}^{-1}$ of $\mathrm{K}_{2} \mathrm{O}$. The application of $\mathrm{K}_{2} \mathrm{O}$ between 88 and $133 \mathrm{~kg} \mathrm{ha}^{-1}$ would generate bigger $\mathrm{Mg}$ and $\mathrm{Zn}$ levels in the cabbage leaves.

The largest biomass of cabbage head with adjacent sheets $(1.42 \mathrm{~kg})$ and the commercial head $(1.23 \mathrm{~kg})$ was obtained with 128 and $123 \mathrm{~kg} \mathrm{ha}^{-1}$ of $\mathrm{K}_{2} \mathrm{O}$, respectively. Thus, the application of $123-$ $128 \mathrm{~kg} \mathrm{ha}^{-1}$ of $\mathrm{K}_{2} \mathrm{O}$ would generate good $\mathrm{Mg}$ and $\mathrm{Zn}$ levels and high cabbage production.

\section{ACKNOWLEDGMENTS}

The authors acknowledge the Instituto Federal de Educação, Ciência e Tecnologia do Triângulo Mineiro (IFTM) for supporting the realization of this study. To the Coordination of Superior Level Staff Improvement (CAPES) for grant scholarship, and Dr. Édimo Fernando Alves Moreira for his support on statistics and data processing.

\section{REFERENCES}

1. Aquino LA, Puiatti M, Pereira PRG, Pereira FHF, Castro MRS, Ladeira IR. Características produtivas do repolho em função de espaçamento e doses de nitrogênio. Hort Bras. 2005;23:266-270, doi: 10.1590/S0102-05362005000200020

2. Silva GS. Adubação fosfatada e potássica para repolho cultivado em latossolo com teor alto dos nutrientes [PhD thesis]. Jaboticabal (SP): Universidade Estadual Paulista "Júlio de Mesquita Filho", Faculdade de Ciências Agrárias e Veterinárias de Jaboticabal; 2012. 36 p.

3. Cecílio Filho AB, Cavarianni RL, Nowaki RHD. Accumulation of macronutrients in cv. 'Astrus' cabbage as influenced by nitrogen dose and plant population. Cienc Investig Agrar. 2016;43(2):305-315, doi: 10.7764/rcia.v43i2.1666

4. Wang M, Zheng Q, Shen Q, Guo S. Review: The critical role of potassium in plant stress response. Int J Mol Sci. 2013;14(1):7370-7390, doi: 10.3390/ijms14047370

5. Domingues Neto FJ, Resende FV, Vidal MC. Cultivares de repolho para a agricultura orgânica nas condições de verão do cerrado. Brasília (DF): Embrapa Hortaliças; 2016. (Boletim de Pesquisa e Desenvolvimento; 141).

6. Duarte LO, Clemente JM, Caixeta IAB, Senoski MP, Aquino LA. Dry matter and nutrient accumulation curve in cabbage crop. Rev Caatinga. 2019;32(3):679-689, doi: 10.1590/1983-21252019v32n312rc

7. Zhang F, Niu J, Zhang W, Cheng X, Li C, Yuan L, Xie J. Potassium nutrition of crops under varied regimes of nitrogen supply. Plant Soil. 2010;335(1-2):21-34, doi: 10.1007/s11104-010-0323-4

8. Beck HE, Zimmermann NE, Mcvicar TR, Vergopolan N, Berg A, Wood EF. Present and future KöppenGeiger climate classification maps at 1-km resolution. Sci Data. 2018;1:1-12, doi: 10.1038/sdata.2018.214

9. Empresa Brasileira de Pesquisa Agropecuária (EMBRAPA). Sistema brasileiro de classificação de solos. 5. ed. Brasília (DF): EMBRAPA; 2018.

10. Raij BVan, Andrade JC, Cantarella H, Quaggio JÁ. Análise química para avaliação da fertilidade de solos tropicais. Campinas (SP): Campinas Instituto Agronômico; 2001.

11. Fontes PCR. Sugestões de adubação para hortaliças. In: Ribeiro AC, Guimarães PTG, Alvares VG, editors. Viçosa (MG): Comissão de Fertilidade do Solo do Estado de Minas Gerais (Recomendações para o uso de corretivos e fertilizantes em Minas Gerais); 1999. p. 171-208.

12. Trani PE, Raij B. Hortaliças. In: Raij B, Cantarella H, Quaggio JA, Furlani AMC, editors. Recomendações de adubação e calagem para o Estado de São Paulo (Boletim Técnico, 100). Campinas (SP): Instituto Agronômico - Fundação IAC; 1997. p.157-185.

13. Carmo CAFS, Araújo WS, Bernardi ACC, Saldanha MFC. Métodos de análise de tecidos vegetais utilizados pela Embrapa Solos. Rio de Janeiro (RJ): Embrapa Solos; 2000.

14. Meurer EJ. Fundamentos de química do solo. 3. ed. Porto Alegre (RS): Evangraf; 2006.

15. Filgueira FAR. Agrotecnologia moderna na produção e comercialização de hortaliças. Novo manual de olericultura. 3rd ed. Viçosa (MG): UFV; 2008. 
16. Berça AS, Mendonça TG, Souza CF. Influence of organic mulching on drip irrigation management of cabbage cultivation. Rev Amb Água. 2019;14(4):e2381, doi: 10.4136/ambi-agua.2381

17. Gmach MR, Cherubin MR, Kaiser K, Cerri CEP. Processes that influence dissolved organic matter in the soil: a review. Sc Agric. 2020;77(3):e20180164, doi: 10.1590/1678-992x-2018-0164

18. Kafkafi U, Xu G, Imas P, Magen H, Tarchitzky J. Potassium and chloride in crops and soils: the role of potassium chloride fertilizer in crop nutrition. IPI Research Topics $\mathrm{n}^{\circ} 22$. Horgen (Switzerlands): International Potash Institute; 2001.

19. Westerveld SM, Mckeown AW, Scottdupree CD. Assessment of chlorophyll and meters as field tissue nitrogen test for cabbage, onions and carrots. Hort Tech. 2004;14:179-188, doi: 10.21273/HORTTECH.14.2.0179

20. Moreira MA, Vidigal SM Evolução das características da planta associadas à nutrição nitrogenada de repolho. Rev Ceres. 2011;58(2):243-248, doi: 10.1590/S0034-737X2011000200017

21. Fontanétti A, Carvalho GJ, Gomes LAA, Almeida K, Moraes SRG, Teixeira CM. Adubação verde na produção orgânica de alface americana e repolho. Hort Bras. 2006;24:146-150, doi: 10.1590/S010205362006000200004

22. Ribas RGT, Cecílio Filho AB, Silva GS. Produtividade do repolho em função de doses de potássio em Latossolo com teor alto do nutriente [Internet]. In: Proceedings of the XXXV Congresso Brasileiro de Ciência do Solo; 2015 Aug 02-07; Natal (RN), Brasil. [place unknown]: The organization; 2015. Available from: https://www.eventossolos.org.br/cbcs2015/arearestrita/arquivos/496.pdf 